\title{
The molecular contribution of TNF- $\alpha$ in the link between obesity and breast cancer
}

\author{
MICHAEL WEICHHAUS, IAIN BROOM and GIOVANNA BERMANO \\ Centre for Obesity Research and Epidemiology (CORE), Faculty of Health and Social Care, \\ Robert Gordon University, St. Andrew Street, Aberdeen, AB25 1HG, UK
}

Received September 29, 2010; Accepted October 27, 2010

DOI: 10.3892/or.2010.1099

\begin{abstract}
Obesity is a growing worldwide medical problem, as it pre-disposes the affected hosts to a number of severe diseases, including postmenopausal breast cancer. Obesity development is characterised, amongst others, by aberrant secretion of adipokines. White fat tissue infiltrating macrophages secrete tumour necrosis factor- $\alpha(\mathrm{TNF}-\alpha)$ so that its circulating levels correlate positively with body mass index (BMI). In the study presented here, the effect of TNF- $\alpha$ on cell proliferation, cell signalling pathway activation and cell cycle in two breast cancer cell lines and one breast epithelial cell lines was assessed to determine the contribution of TNF- $\alpha$ on breast cancer progression and aetiology, respectively. TNF- $\alpha$ acted differently on all three cell lines. In MDA-MB-231 breast cancer cells, cell proliferation and PI3-kinase activation were not affected, while MAP-kinase activation and cell cycle progression were decreased, with indications of increased apoptosis. This suggests a growth inhibitory function of TNF- $\alpha$ in these cells. In SK-BR-3 breast cancer cells, cell proliferation and cell signalling pathway activation increased, while cell cycle progression decreased, which contradictorily suggests both growth promoting and growth inhibiting properties of TNF- $\alpha$ on these cells. This makes TNF- $\alpha$ an unlikely candidate for a general contribution to the link between obesity and breast cancer progression, however, individual tumours may be responsive to a proliferative signal of TNF- $\alpha$. In MCF-10A breast epithelial cells, cell proliferation and MAP-kinase activation increased, while cell cycle progression was unaffected. This suggests a strong proliferative response in these cells, suggesting the possibility that TNF- $\alpha$ may contribute to breast cancer aetiology as a novel link between obesity and increased risk of breast cancer development.
\end{abstract}

Correspondence to: Dr Giovanna Bermano, Centre for Obesity Research and Epidemiology (CORE), Faculty of Health and Social Care, Robert Gordon University, St. Andrew Street, Aberdeen, AB25 1HG, UK

E-mail: g.bermano@rgu.ac.uk

Key words: obesity, breast cancer, TNF- $\alpha$

\section{Introduction}

Obesity is a risk factor for the development of postmenopausal breast cancer (1-3). Despite numerous studies, the molecular mechanism by which obesity may contribute to breast cancer aetiology and progression is still poorly understood, suggesting a complex multi-mechanism of interaction. Obesity is characterised, amongst others, by a change in adipocyte secreted adipokines (4-6). Plasma concentrations of several well-known adipokines are positively correlated with BMI, such as leptin (7), interleukin-6 (IL-6) (8) and tumour necrosis factor- $\alpha(\mathrm{TNF}-\alpha)(9)$. In the study presented here, the contribution of TNF- $\alpha$ in the link between obesity and progression or aetiology of breast cancer is assessed.

TNF- $\alpha$ is a cytokine involved in the induction of inflammation and initiation of an acute phase immune response. When cells are stimulated to secrete $\mathrm{TNF}-\alpha$, membrane-bound precursor molecules on the surface of secreting cells are cleaved to form $51 \mathrm{kDa}$ circulating TNF- $\alpha$, consisting of three $17 \mathrm{kDa}$ TNF- $\alpha$ molecules (10). Its name derived from the initial observation that this cytokine was able to induce cell death in the murine fibrosarcoma L-929 cell line (11). Endocrine signalling is accomplished by circulating TNF- $\alpha$ binding to and activating its specific receptor TNF-receptor 1 (TNF-R1) on target cells. The receptor is expressed ubiquitously in all human tissues, including breast epithelial cells (12). Thus TNF- $\alpha$ signalling in breast epithelial cells and breast cancer cells could be affected by obesity associated increases in TNF- $\alpha$ circulatory concentration.

Previous in vitro studies observed conflicting results as to the effect of TNF- $\alpha$ on growth promotion in breast cancer cells. It was found that $20 \mathrm{ng} / \mathrm{ml} \mathrm{TNF- \alpha} \mathrm{increased} \mathrm{cell}$ proliferation in T47D human breast cancer cells and induced significant activation of PI3-kinase pathway, MAP-kinase pathway and JAK/STAT pathway (13), suggesting a growth promoting effect of TNF- $\alpha$ on these cells. Conversely, treatment with $10 \mathrm{ng} / \mathrm{ml} \mathrm{TNF- \alpha}$ for $24 \mathrm{~h}$ increased G1-phase population, while reducing the cell population in S-phase and G2-phase (14), suggesting a cell cycle inhibiting effect on these cells. Thus TNF- $\alpha$ had different, indeed opposing effects on T47D breast cancer cells. In MCF-7 breast cancer cells $10 \mathrm{ng} / \mathrm{ml} \mathrm{TNF-} \alpha$ decreased cell proliferation (15) and an increase in G1-phase cell population was observed after treatment with $10 \mathrm{ng} / \mathrm{ml} \mathrm{TNF- \alpha}$ for $36 \mathrm{~h}$ in MCF-7 cells (16), 
suggesting a growth inhibiting effect in this cell line. In different MCF-7 cell subtypes, however, opposing effects of TNF- $\alpha$ on cell proliferation were observed (17). Thus, the effect of TNF- $\alpha$ on breast cancer cell growth is not elucidated satisfactorily, while the effect of TNF- $\alpha$ on human breast epithelial cells has not been investigated at all.

The study presented here aimed to assess the effect of TNF- $\alpha$ on cell proliferation, PI3-kinase and MAP-kinase cell signalling pathway activation and on changes in the distribution of the cell population across cell cycle stages in an in vitro cell culture model. It was of particular interest to determine the possible different impact of TNF- $\alpha$ on breast cancer cells compared to normal breast epithelial cells as a novel way of assessing the molecular mechanisms involved in the link between obesity and breast cancer progression and aetiology. In order to assess the contribution of TNF- $\alpha$ on breast cancer progression, two breast cancer cell lines were selected, MDA-MB-231 and SK-BR-3 breast cancer cells. The contribution of TNF- $\alpha$ on breast cancer aetiology was assessed using normal MCF-10A breast epithelial cells. Previous experiments were performed in oestrogen receptor (ER) positive cells. In the study presented here, ER negative cell lines were used.

\section{Materials and methods}

Materials. Human Caucasian breast adenocarcinoma cells MDA-MB-231 (Cat No. 92020424, passage No. 36) were purchased from the European Collection of Cell Cultures (ECACC, Salisbury, UK). Human Caucasian breast adenocarcinoma cells SK-BR-3 (ATCC No. HTB-30, passage No. 28) were purchased from the American Type Culture Collection (ATCC, Manassas, USA). MDA-MB 231 cells and SK-BR-3 cells were routinely cultured in RPMI-1640 Medium (including $25 \mathrm{mM}$ HEPES, 1x Glutamax) [Gibco (Invitrogen), Paisley, UK, Cat No. 72400] supplemented with $10 \%$ FCS (Pierce Biosciences, Cramlington, UK, Cat No. CHD0413) and $100 \mathrm{U} / \mathrm{ml}$ penicillin and $100 \mu \mathrm{g} / \mathrm{ml}$ streptomycin (Gibco, Cat No. 15140). MDA-MB-231 breast cancer cells have mutations in genes coding for RAS and RAF, increasing their kinase activity, while SK-BR-3 breast cancer cells possess wild-type genes coding for RAS and RAF (18). RAS and RAF are kinase members of the MAPkinase cell signalling pathway. Human Caucasian breast epithelial cells MCF-10A (ATCC No. CRL-10317, passage No. 102) were purchased from ATCC and were cultured in DMEM/F-12 Medium (BioWhittaker, UK [Lonza Biologics], Slough, UK, Cat No. BE12-7199) supplemented with 5\% Horse Serum (Sigma-Aldrich, Gillingham, UK, Cat No. H1138), $10 \mu \mathrm{g} / \mathrm{ml}$ human insulin (Sigma, Cat No. I9278), $0.5 \mu \mathrm{g} / \mathrm{ml}$ hydrocortisone (Sigma, Cat No. H0888), $20 \mu \mathrm{g} / \mathrm{ml}$ human epidermal growth factor (Invitrogen, Cat No. 13247051), $100 \mathrm{ng} / \mathrm{ml}$ cholera toxin (Sigma, Cat No. 8052), $50 \mathrm{U} / \mathrm{ml}$ penicillin and $50 \mu \mathrm{g} / \mathrm{ml}$ streptomycin (Gibco). Starvation medium was RPMI-1640 (25 mM HEPES, 1x Glutamax) (Gibco) supplemented with $100 \mathrm{U} / \mathrm{ml}$ penicillin and $100 \mu \mathrm{g} / \mathrm{ml}$ streptomycin (Gibco) for MDA-MB 231 cells and SK-BR-3 cells and DMEM/F12 (BioWhittaker) supplemented with $100 \mathrm{U} / \mathrm{ml}$ penicillin and $100 \mu \mathrm{g} / \mathrm{ml}$ streptomycin for MCF$10 \mathrm{~A}$ cells. Human recombinant TNF- $\alpha$ was purchased from
Sigma (Cat No. T0157). Cell culture conditions were $37^{\circ} \mathrm{C}$ in humidified air supplemented to contain $5 \% \mathrm{CO}_{2}$.

BrdU-incorporation assay. Cell proliferation was detected using a colorimetric Cell Proliferation ELISA Kit (Roche Diagnostics, Penzberg, Germany, Cat No. 11647229 001), which assesses DNA replication by measuring bromodeoxyuridine (BrdU) incorporation. Cells $\left(5 \times 10^{3}\right.$ cells/well $)$ from each cell line were plated in 96-well plates (Fisher Scientific, Cat No. 167008) with $100 \mu 1$ /well growth medium and incubated for $24 \mathrm{~h}$ at $37^{\circ} \mathrm{C}$. Cells were washed once in $100 \mu \mathrm{l} /$ well sterile PBS and incubated in starvation medium for $24 \mathrm{~h}$. After starvation, cells were washed as before and treated for 24 or $48 \mathrm{~h}$ with $10 \mathrm{ng} / \mathrm{ml} \mathrm{TNF}-\alpha$ in $100 \mu \mathrm{l} /$ well starvation medium. During treatment, medium was supplemented with $10 \mu \mathrm{M}$ BrdU. Incorporated BrdU was detected according to the manufacturer's instructions. In brief, cells were fixed and incubated with supplied peroxidase conjugated anti-BrdU antibody. Bound antibody was detected by colorimetric turn-over. Colour development was quantified on $\mu$ Quant microplate spectrophotometer (BioTek, UK) by measuring absorption at $450 \mathrm{~nm}$ with a reference wavelength of $690 \mathrm{~nm}$. Three experiments were performed for each cell line and each time point. Each experiment consisted of six replicates for each treatment, i.e. six wells for control and six wells for treatment.

Phospho-kinase ELISA. Cell-based ELISA phospho-AKT (S473) immunoassay (Cat No. KCB887) and phosphoERK1/ERK2 (T202/Y204) immunoassay (Cat No. KCB1018) were purchased from R\&D Systems (Abingdon, UK). Cells from all three cell lines were plated into a supplied clear bottom black 96-well plate at a density of $5 \times 10^{3}$ cells/ well with $100 \mu \mathrm{l} /$ well growth medium and incubated for $24 \mathrm{~h}$ at $37^{\circ} \mathrm{C}$. Cells were washed once in $100 \mu \mathrm{l} /$ well sterile PBS and incubated in starvation medium for $24 \mathrm{~h}$. After starvation, cells were washed as before and treated with $10 \mathrm{ng} / \mathrm{ml}$ TNF- $\alpha$ in $100 \mu \mathrm{l} /$ well starvation medium for times indicated in Fig. 2. Phosphorylation of AKT and ERK1/2 was then assessed following the manufacturer's instructions. In brief, after fixing, the cells were incubated with anti-phospho-AKT or anti-phospho-ERK1/2 specific antibody in conjunction with anti-total AKT or anti-total ERK1/2 specific antibody, respectively. Phospho-specific antibodies were of mouse origin, while antibodies for the total protein were produced in rabbits. Each antibody was identified by mouse or rabbit specific secondary antibodies, which were tagged with HRP or AP, respectively, allowing for simultaneous quantification of phosphorylated and total AKT or ERK1/2 protein. After antibody incubation, excess secondary antibody was removed by several washes in supplied wash buffer and PBS, before two supplied fluorescent substrates were added. Fluorescence was measured on Fluoroskan Ascent microplate reader (Labsystem, UK) with excitation at $544 \mathrm{~nm}$ and emission at $590 \mathrm{~nm}$ (phosphorylated protein), followed by a second read with excitation at $355 \mathrm{~nm}$ and emission at $460 \mathrm{~nm}$ (total protein). For each cell line two experiments were performed to assess AKT-phosphorylation and two to assess ERK1/2phosphorylation after TNF- $\alpha$ treatment. Each experiment included two replicates for each treatment time and the control. 
A

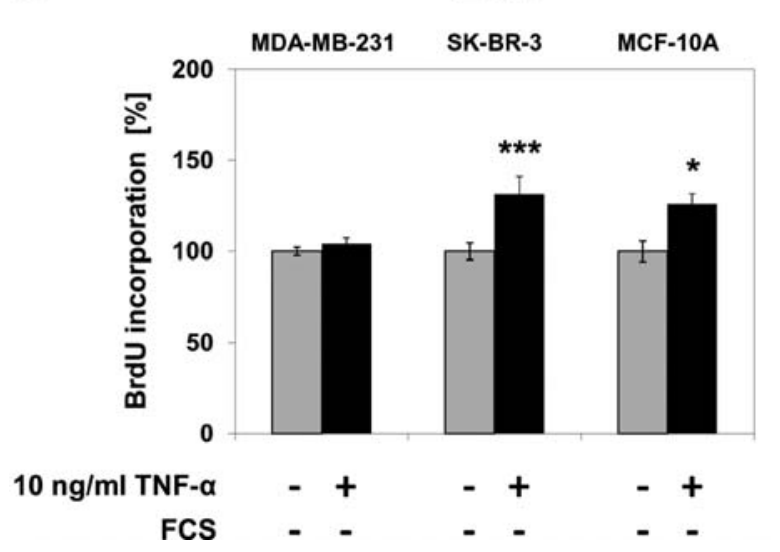

B

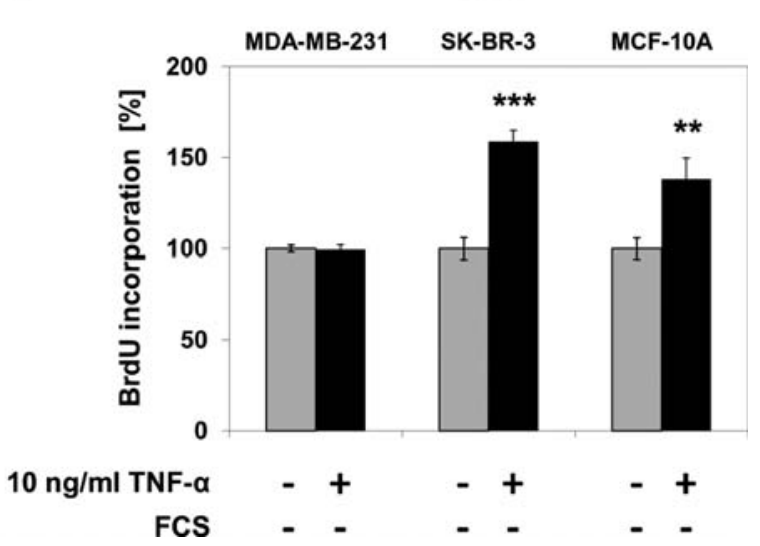

Figure 1. Changes in cell proliferation after treatment with $10 \mathrm{ng} / \mathrm{ml} \mathrm{TNF- \alpha} \mathrm{(A)} 24 \mathrm{~h}$ or (B) $48 \mathrm{~h}$ in MDA-MB-231 breast cancer cells, SK-BR-3 breast cancer cells and MCF-10 breast epithelial cells. Bars represent BrdU-incorporation in relation to the respective control and are expressed as a percentage thereof. Error bars represent \pm SEM of three experiments, each consisting of six replicates, i.e. 18 data points for each bar. ${ }^{*}$ Significance value compared to control, obtained using one-way ANOVA analysis. $\left({ }^{*} 0.05>\mathrm{p}>0.01 ;{ }^{* *} 0.01>\mathrm{p}>0.001 ;{ }^{* * *} \mathrm{p}<0.001\right)$

Flow cytometry. Changes in the cell distribution across cell cycle stages were assessed by measurement of DNA-content in cells. The DNA specific dye was propidium iodide (PI) (Sigma, Cat No. P4170). Cells were plated at $5 \times 10^{5}$ cells/ well in 6-well plates with $3 \mathrm{ml}$ growth medium and incubated for $24 \mathrm{~h}$ at $37^{\circ} \mathrm{C}$. Cells were starved for $24 \mathrm{~h}$ and then treated with $10 \mathrm{ng} / \mathrm{ml} \mathrm{TNF}-\alpha$ for $24 \mathrm{~h}$. Cells were harvested by trypsin, centrifuged at $500 \mathrm{x}$ g for $5 \mathrm{~min}$ and each sample was resuspended in $100 \mu 1 \mathrm{PBS}$ and $900 \mu 170 \%$ (v/v) icecold ethanol before being incubated at $4^{\circ} \mathrm{C}$ for $30 \mathrm{~min}$. Samples were centrifuged at $10,000 \mathrm{x}$ g for $5 \mathrm{~min}$, resuspended in $1 \mathrm{ml}$ PBS and again centrifuged at $10,000 \mathrm{x} \mathrm{g}$ for $5 \mathrm{~min}$. Pellet was resuspended in $500 \mu 1$ extraction buffer $(4 \mathrm{mM}$ citric acid, 0.2 $\mathrm{M} \mathrm{Na}_{2} \mathrm{HPO}_{4}, \mathrm{pH} 7.8$ ) and $500 \mu \mathrm{l} \mathrm{PBS}$ and incubated at room temperature for $5 \mathrm{~min}$. Cells were centrifuged at $10,000 \mathrm{x}$ g for $5 \mathrm{~min}$ and the pellet was resuspended in $500 \mu \mathrm{l}$ DNA staining solution $(20 \mu \mathrm{g} / \mathrm{ml}$ propidium iodide and $0.2 \mathrm{mg} / \mathrm{ml}$ DNase free RNase). The cells were incubated at room temperature for $30 \mathrm{~min}$. Flow cytometry of PI stained cells was performed using a Coulter Epics XLMCL flow cytometer (Beckman Coulter, UK). Data were captured and analysed using EXPO 32 Software (Applied Cytometry Systems, Sheffield, UK). Cell cycle distribution was assessed from linear FL-2 area vs. width plots. The percentage of cells in the three cell cycle phases (G1, S and G2) was calculated from histograms of linear FL-2 area plots after assessing 10,000 events. Additionally, percentage of cells with a DNA content $<2 \mathrm{~N}$ (sub-G1) was measured as an indication of apoptosis. Three experiments were performed for each cell line, containing two replicates for control and treatment.

Statistical analysis. Cell proliferation results were assessed using one-way ANOVA. Cell signalling pathway activation and cell cycle results were assessed using Dunnett's post-hoc t-test following univariate analysis of variance. Changes were defined as significantly different at $\mathrm{p}<0.05$.

\section{Results}

Cell proliferation. Cell proliferation of all cell lines was assessed after $10 \mathrm{ng} / \mathrm{ml} \mathrm{TNF- \alpha}$ treatment for 24 or $48 \mathrm{~h}$ (Fig. 1). Untreated control cells were incubated in starvation medium (Control) at all times. All results are presented as percentage change from this control. In MDA-MB-231 breast cancer cells, cell proliferation did not significantly change after 24or 48-h treatment with $10 \mathrm{ng} / \mathrm{ml} \mathrm{TNF-} \alpha$. In SK-BR-3 breast cancer cells, cell proliferation increased significantly by $31 \%$ after 24 -h treatment $(\mathrm{p}=0.016)$ and by $59 \%$ after 48 -h treatment $(\mathrm{p}<0.001)$ with $10 \mathrm{ng} / \mathrm{ml}$ TNF- $\alpha$. In MCF-10A normal breast epithelial cells, cell proliferation increased significantly by $26 \%$ after 24 -h treatment $(\mathrm{p}<0.001)$ and by $38 \%$ after 48-h treatment $(\mathrm{p}=0.002)$ with $10 \mathrm{ng} / \mathrm{ml} \mathrm{TNF-} \alpha$.

Cell signalling pathway activation. Phosphorylation of AKT or ERK1/2 was measured after treatment with $10 \mathrm{ng} / \mathrm{ml}$ TNF- $\alpha$ for between 5-20 min (Fig. 2). Untreated control cells were incubated in starvation medium (Control) at all times. All results are presented as percentage change of this control. In MDA-MB-231 breast cancer cells, AKT-phosphorylation did not change significantly after treatment between 5 and $20 \mathrm{~min}$ with $10 \mathrm{ng} / \mathrm{ml} \mathrm{TNF}-\alpha$. ERK1/2-phosphorylation was significantly decreased by $22 \%$ after 5 -min treatment ( $\mathrm{p}=0.044$ ) with $10 \mathrm{ng} / \mathrm{ml}$ TNF- $\alpha$ (Fig. 2A). In SK-BR-3 breast cancer cells, AKT-phosphorylation increased significantly by 66,72 and $91 \%$ after $5-\min (\mathrm{p}=0.04), 10-\mathrm{min}(\mathrm{p}=0.025)$ and $20-$ min treatment $(\mathrm{p}=0.006)$ with $10 \mathrm{ng} / \mathrm{ml} \mathrm{TNF-} \alpha$, respectively compared to untreated control. ERK1/2phosphorylation increased significantly by $47 \%$ after 5 -min treatment $(\mathrm{p}=0.027)$ with $10 \mathrm{ng} / \mathrm{ml} \mathrm{TNF}-\alpha$ (Fig. 2B). In MCF-10A normal breast epithelial cells, AKT-phosphorylation did not change significantly. A non-significant increase of $77 \%(p=0.169)$ after 20 min of treatment with $10 \mathrm{ng} / \mathrm{ml}$ TNF- $\alpha$ compared to untreated control was, however, observed. ERK1/2-phosphorylation increased 
A

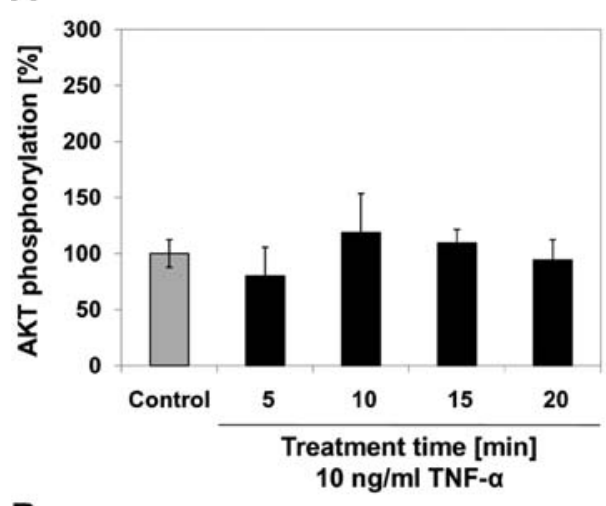

B

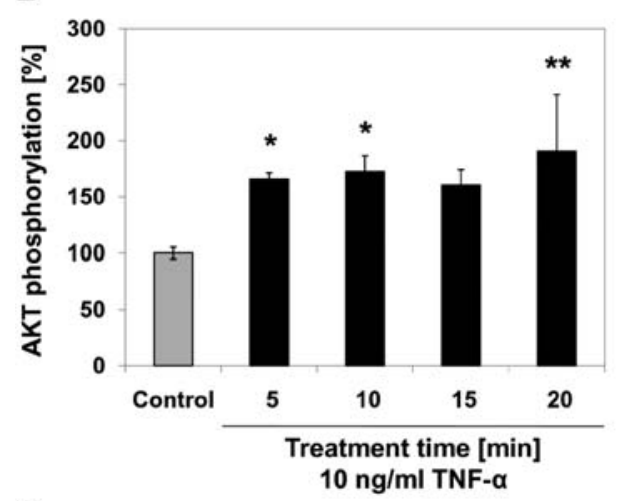

C

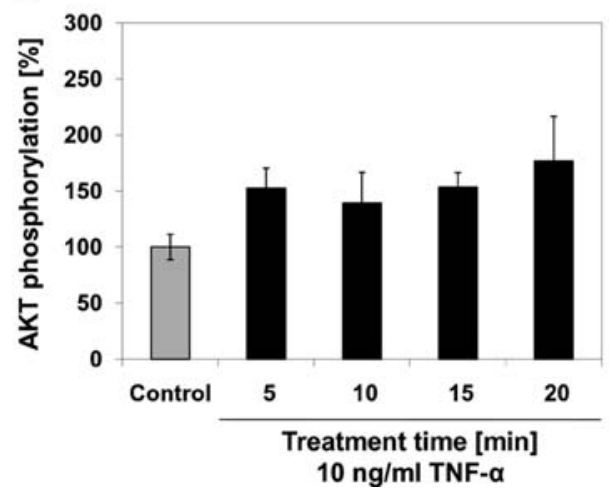

MDA-MB-231

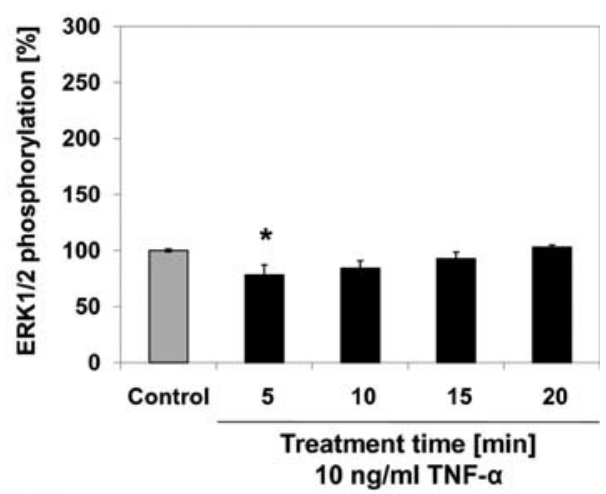

SK-BR-3

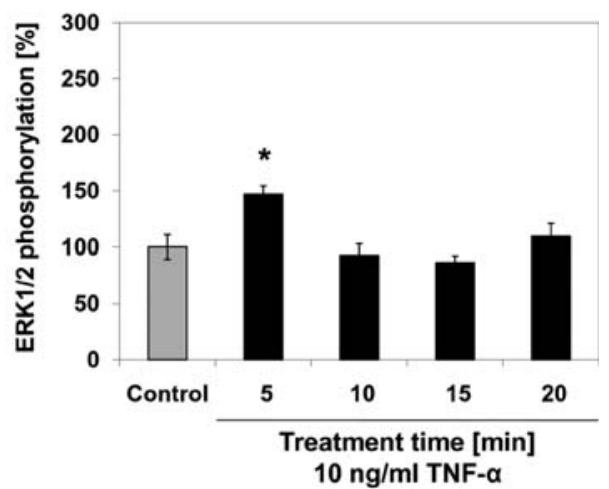

MCF-10A

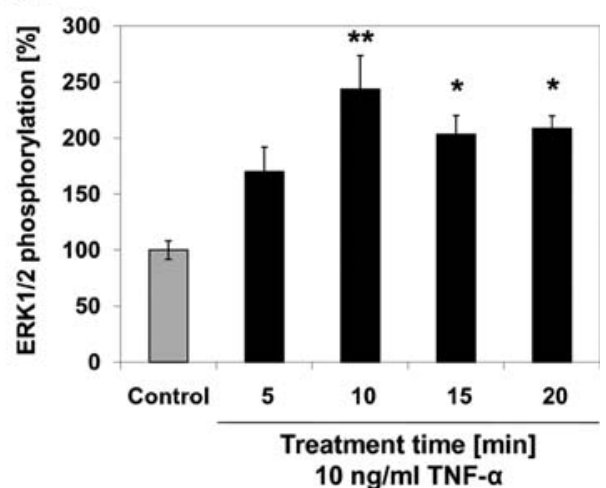

Figure 2. Changes in cell signalling pathway activation [PI3-kinase (left) and MAP-kinase (right))] with $10 \mathrm{ng} / \mathrm{ml}$ TNF- $\alpha$ treatment in (A) MDA-MB-231 breast cancer cells (B) SK-BR-3 breast cancer cells and (C) MCF-10A breast epithelial cells. Bars represent AKT-phosphorylation or ERK1/2-phosphorylation in relation to the respective control within each graph and are expressed as a percentage thereof. Error bars represent \pm SEM of two experiments, each consisting of two replicates, i.e. four data points for each bar. *Significance value compared to control, obtained using Dunnett's post-hoc t-test following univariate analysis of variance. $\left({ }^{*} 0.05>\mathrm{p}>0.01 ;{ }^{* *} 0.01>\mathrm{p}>0.001\right)$.

significantly by 144,103 and $108 \%$ after $10-\min (\mathrm{p}=0.003)$, $15-\min (\mathrm{p}=0.025)$ and 20 -min treatment $(\mathrm{p}=0.019)$ with $10 \mathrm{ng} / \mathrm{ml} \mathrm{TNF-} \alpha$ compared to untreated control (Fig. 2C).

Cell cycle. Cell cycle profiles for all cell lines were established

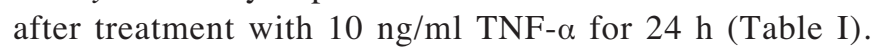
In MDA-MB-231 breast cancer cells, population of the G1phase decreased significantly by 3.5 percentage points (a $6 \%$ decrease) after 24-h treatment ( $\mathrm{p}=0.006)$ with $10 \mathrm{ng} / \mathrm{ml} \mathrm{TNF}-\alpha$ compared to G1-phase population of control cells. S-phase population decreased significantly by 1.8 percentage points (a 15\% decrease) after 24-h treatment $(\mathrm{p}<0.001)$ with $10 \mathrm{ng} / \mathrm{ml}$ TNF- $\alpha$ compared to S-phase population of control cells. No significant difference in G2-phase population after 24-h treatment $(\mathrm{p}=0.233)$ with $10 \mathrm{ng} / \mathrm{ml} \mathrm{TNF}-\alpha$ compared to G2phase population of control cells was observed. Additionally, the sub-G1 population increased significantly by 4.66 percentage points (a $27 \%$ increase) after treatment with $10 \mathrm{ng} / \mathrm{ml} \mathrm{TNF}-\alpha$ for $24 \mathrm{~h}(\mathrm{p}<0.001)$. In SK-BR-3 breast cancer cells G1-phase population was not significantly different between 24-h treatment $(\mathrm{p}=0.811)$ with $10 \mathrm{ng} / \mathrm{ml}$ TNF- $\alpha$ and the control. Population of the S-phase decreased significantly by 1.5 percentage points (a $25 \%$ decrease) after 24-h treatment $(\mathrm{p}=0.011)$ with $10 \mathrm{ng} / \mathrm{ml} \mathrm{TNF-} \alpha$ compared to S-phase population of control cells. Population of the G2phase decreased significantly by 3.8 percentage points (a $24 \%$ decrease) after 24-h treatment $(\mathrm{p}=0.011)$ with $10 \mathrm{ng} / \mathrm{ml}$ TNF- $\alpha$ compared to G2-phase population of control cells. In 
Table I. Changes of cell population distribution across cell cycle stages after 24-h treatment with $10 \mathrm{ng} / \mathrm{ml}$ TNF- $\alpha$ in MDAMB-231 cells, SK-BR-3 cells and MCF-10A cells.

\begin{tabular}{|c|c|c|c|c|}
\hline & Sub-G1 (\%) & G1/G0 (\%) & $\mathrm{S}(\%)$ & $\mathrm{G} 2(\%)$ \\
\hline \multicolumn{5}{|l|}{ MDA-MB-231 } \\
\hline Control & $16.98 \pm 1.07$ & $55.12 \pm 0.40$ & $7.23 \pm 0.65$ & $12.88 \pm 0.43$ \\
\hline $10 \mathrm{ng} / \mathrm{ml} \mathrm{TNF}-\alpha$ for $24 \mathrm{~h}$ & $21.64 \pm 1.44$ & $51.64 \pm 1.14$ & $5.43 \pm 0.58$ & $12.38 \pm 0.42$ \\
\hline UNIANOVA & $\mathrm{p}<0.001$ & $\mathrm{p}=0.006$ & $\mathrm{p}<0.001$ & ns \\
\hline \multicolumn{5}{|l|}{ SK-BR-3 } \\
\hline Control & $21.25 \pm 1.41$ & $39.90 \pm 2.00$ & $6.30 \pm 0.45$ & $15.98 \pm 0.70$ \\
\hline $10 \mathrm{ng} / \mathrm{ml} \mathrm{TNF}-\alpha$ for $24 \mathrm{~h}$ & $26.62 \pm 3.85$ & $37.97 \pm 1.14$ & $4.75 \pm 0.91$ & $12.19 \pm 1.87$ \\
\hline UNIANOVA & ns & ns & $\mathrm{p}=0.011$ & $\mathrm{p}=0.011$ \\
\hline \multicolumn{5}{|l|}{ MCF-10A } \\
\hline Control & $23.17 \pm 1.28$ & $65.23 \pm 1.50$ & $1.27 \pm 0.09$ & $6.60 \pm 0.41$ \\
\hline $10 \mathrm{ng} / \mathrm{ml} \mathrm{TNF}-\alpha$ for $24 \mathrm{~h}$ & $27.50 \pm 2.33$ & $58.61 \pm 2.54$ & $1.54 \pm 0.19$ & 7.600 .76 \\
\hline UNIANOVA & ns & $\mathrm{p}=0.051$ & ns & ns \\
\hline
\end{tabular}

Values represent mean \pm standard error of three independent experiments. Each experiment had two replicates, i.e. six data points for control and treatment. ns, not significant.

MCF-10A normal breast epithelial cells no significant difference in any cell cycle phase was observed after 24-h treatment with $10 \mathrm{ng} / \mathrm{ml} \mathrm{TNF-} \alpha$ compared to control. In the G1-phase population a non-significant decrease of 6.6 percentage points (a $12 \%$ decrease) after 24-h treatment $(\mathrm{p}=0.051)$ with $10 \mathrm{ng} / \mathrm{ml} \mathrm{TNF}-\alpha$ compared to G1-phase population of control cells was observed.

\section{Discussion}

Adipokines have been hypothesised as molecular explanation of the link between obesity and increased risk of developing postmenopausal breast cancer (19-21). Both leptin (22-26) and adiponectin $(22,27-29)$ have been studied in in vitro systems and results have indicated that there is some involvement, even though their effect on breast cancer is diametrically opposed. Their effect on growth promotion in breast cancer cells, however, is small and suggests that additional factors may play a role. The fact that many more adipokines have been discovered recently, the expression of which being affected by obesity, makes the contribution of other adipokines in the molecular link between obesity and postmenopausal breast cancer likely. The effects of TNF- $\alpha$ on a breast cancer cell model were therefore studied to evaluate the contribution of $\mathrm{TNF}-\alpha$ in the link between obesity and breast cancer progression. Additionally, a normal breast epithelial cell line was used to examine the potential impact of TNF- $\alpha$ on breast cancer aetiology. The impact of TNF- $\alpha$ on breast epithelial cells has not been assessed previously and represents a novel way of assessing the impact of adipokines on breast cancer aetiology.

In MDA-MB-231 breast cancer cells, cell proliferation did not change after 24- or 48-h treatment with $10 \mathrm{ng} / \mathrm{ml}$ TNF- $\alpha$. Similarly, Mueller and his colleagues observed that
$0.25 \mathrm{nM}(12.75 \mathrm{ng} / \mathrm{ml}) \mathrm{TNF}-\alpha$ treatment alone did not change cell proliferation in these cells (30). Thus, there is no indication that TNF- $\alpha$ increases cell proliferation in these cells. In SKBR-3 breast cancer cells, $10 \mathrm{ng} / \mathrm{ml} \mathrm{TNF-} \alpha$ treatment increased cell proliferation after 24 and $48 \mathrm{~h}$ of treatment. The highest increased was observed after 48 -h treatment. Similarly, Rivas and colleagues observed an increase in SK-BR-3 cell proliferation following $20 \mathrm{ng} / \mathrm{ml} \mathrm{TNF-} \alpha$ treatment for $48 \mathrm{~h}$ (31). There is, therefore, good evidence that TNF- $\alpha$ has a proliferative effect on SK-BR-3 breast cancer cells. Hence, cell proliferation of the two breast cancer cell lines reacted differently to treatment with TNF- $\alpha$. While both cell lines are ER-negative, there is a difference in HER2 expression with SK-BR-3 cells expressing high levels and MDA-MB-231 cell expressing low levels (32). In addition, MDA-MB-231 cells carry mutations in the genes coding for kinases RAS and RAF, that form part of the MAP-kinase cell signalling pathway (18). These differences may contribute to the different effect of TNF- $\alpha$ on these cells, which may also apply to the other differences observed. In MCF-10A breast epithelial cells, treatment with $10 \mathrm{ng} / \mathrm{ml} \mathrm{TNF}-\alpha$ increased cell proliferation after 24 and $48 \mathrm{~h}$. In rat breast epithelial cells TNF- $\alpha$ treatment similarly increased proliferation $(33,34)$. Our results indicate that TNF- $\alpha$ treatment has a substantial and sustained effect on promoting cell proliferation in MCF-10A cells.

PI3-kinase signalling is involved in breast cancer development, its activation being linked to increased cell growth (35). In MDA-MB-231 breast cancer cells, TNF- $\alpha$ treatment did not change phosphorylation of AKT, while in SK-BR-3 breast cancer cells, $10 \mathrm{ng} / \mathrm{ml} \mathrm{TNF-} \alpha$ treatment increased phosphorylation of AKT. These are novel findings as no other studies investigated the phosphorylation of AKT after treatment with TNF- $\alpha$ in these cells. In one study, TNF- $\alpha$ mediated activation of AKT has been linked to activation of 
proliferation-stimulating transcription factor NF-кB in T47D breast cancer cells (13). Thus, similarly activation of AKT may be a pathway for TNF- $\alpha$ stimulated cell proliferation in SK-BR-3 breast cancer cells. In MCF-10A breast epithelial cells, $10 \mathrm{ng} / \mathrm{ml} \mathrm{TNF-} \alpha$ treatment did not change AKT-phosphorylation significantly. A non-significant increase of $77 \%$ in AKT-phosphorylation after 20-min treatment was, however, observed.

MAP-kinase signalling is involved in promoting cell proliferation and apoptosis evasion in breast cancer cells $(36,37)$. TNF- $\alpha$ treatment significantly decreased phosphorylation of ERK1/2 in MDA-MB-231 breast cancer cells. In the only comparable study, treatment of MDA-MB-231 breast cancer cells with $10 \mathrm{ng} / \mathrm{ml} \mathrm{TNF- \alpha}$ for $24 \mathrm{~h}$ induced expression of MMP-9, which was reduced after inhibition of MEK1/2 by $10 \mu \mathrm{M}$ U0126, suggesting that TNF- $\alpha$ activates ERK1/2 to exert this effect (38). This study, however, did not examine ERK1/2-phosphorylation directly. Thus, there is no confirmation to this finding. Additionally, ERK1/2phosphorylation slowly and non-significantly increased between 5 and $20 \mathrm{~min}$ of treatment. Extension of treatment time may be needed to determine, if this trend continues and TNF- $\alpha$ treatment has a time-delay in inducing ERK1/2phosphorylation after increased treatment time. A reduction in ERK1/2-phosphorylation is explained by TNF- $\alpha$ 's interference with the, by mutation of RAS and RAF, constitutively activated MAP-kinase pathway. It also indicates, however, a growth inhibitory effect of TNF- $\alpha$ on these cells, which in the previous results had not been observed. In SK-BR-3 breast cancer cells, $10 \mathrm{ng} / \mathrm{ml} \mathrm{TNF-} \alpha$ treatment significantly increased phosphorylation of ERK1/2. This is a novel finding and further supports the growth promoting effect of TNF- $\alpha$ in this breast cancer cell line. With both PI3kinase and MAP-kinase pathway activated in response to TNF- $\alpha$ treatment, it can not be ascertained which pathway may promote the observed increase in cell proliferation. In MCF-10A breast epithelial cells, $10 \mathrm{ng} / \mathrm{ml}$ TNF- $\alpha$ increased phosphorylation of ERK1/2 significantly after between 10- and 20-min treatment. The highest increase was observed after 10-min treatment. This indicates a sustained activation of at least $10 \mathrm{~min}$. The non-significant increase in AKTphosphorylation may suggest that the MAP-kinase may be majorly responsible for mediating $\mathrm{TNF}-\alpha$ induced cell proliferation in this cell line.

In MDA-MB-231 breast cancer cells, $10 \mathrm{ng} / \mathrm{ml} \mathrm{TNF}-\alpha$ treatment for $24 \mathrm{~h}$ significantly decreased the G1- and S-phase population of the cell cycle profile. In addition, cells with a DNA-content below that expected of cells in G1-phase were measured. These cells were indicative of apoptotic cells. In MDA-MB-231 breast cancer cells, this 'subG1' population increased significantly after TNF- $\alpha$ treatment. This suggests that TNF- $\alpha$ may promote apoptosis in these cells. This is a novel finding and in addition to the decrease in ERK1/2 phosphorylation after TNF- $\alpha$ treatment suggests a growth inhibiting and even apoptosis inducing effect of TNF- $\alpha$ on MDA-MB-231 breast cancer cells. In SK-BR-3 breast cancer cells, $10 \mathrm{ng} / \mathrm{ml} \mathrm{TNF-} \alpha$ treatment significantly decreased S-phase and G2-phase population after 24-h treatment. There was, however, no indication of increased apoptosis. A similar result was observed for T47D breast cancer cells, where S-phase and G2-phase decreased after treatment with $10 \mathrm{ng} / \mathrm{ml} \mathrm{TNF-} \alpha$ for $24 \mathrm{~h}$ (14). These authors concluded that TNF- $\alpha$ induced cell cycle arrest at the G1/S cell cycle checkpoint (14), which may similarly apply to SK-BR-3 breast cancer cells. Cell cycle arrest is typically associated with growth inhibition, thus, the cell cycle results oppose the previous findings, all of which could be interpreted as TNF- $\alpha$ promoting cell growth in SK-BR-3 breast cancer cells. There is no conclusive explanation for this observation. One may be confronted with a similar situation as observed for different subtypes of the MCF-7 breast cancer cell line, which showed opposing effects to TNF- $\alpha$ treatment (17). In MCF-10A breast epithelial cells, $10 \mathrm{ng} / \mathrm{ml} \mathrm{TNF-} \alpha$ did not change the distribution of the cell population across cell cycle phases. G1-phase population decreased non-significantly after $\mathrm{TNF}-\alpha$ treatment $(\mathrm{p}=0.051)$. The probability value is just above the cut-off point. A decrease in G1phase population could be interpreted as an increase in cell cycle progression, thus complementing findings from the cell proliferation results and cell signalling pathways. This suggests that all experiments point to an increase in cell growth in MCF-10A cells, following TNF- $\alpha$ treatment.

In conclusion, TNF- $\alpha$ affects the metabolism of breast cancer cells and breast epithelial cells. The effect on breast cancer cells is, however, not as comprehensive as the effect on breast epithelial cells. In MDA-MB-231 breast cancer cells the results generally suggest no effect on cell growth, with some indications of growth inhibition and even increased apoptosis after TNF- $\alpha$ treatment. Conversely, results for SK-BR-3 cells generally indicate a growth promoting effect of TNF- $\alpha$, while the cell cycle results are contradicting these findings. TNF- $\alpha$ exerts different and even opposing effects between just two breast cancer cell lines, suggesting there is no general mode of action of TNF- $\alpha$ on breast cancer cells, but that different cells, and thus tumours, may react differently to increased $\mathrm{TNF}-\alpha$ concentrations. If one assumes cell mosaicism in tumours, one may also speculate that cells of the same tumour could react differently to TNF- $\alpha$. As the majority of our results indicate growth promotion in SK-BR-3 breast cancer cells, TNF- $\alpha$ can not be excluded as a potential mediator in the link between obesity and breast cancer progression. In MCF-10A breast epithelial cells, TNF- $\alpha$ increases cell proliferation, with no indication of cell cycle arrest or onset of apoptosis. This significant finding introduces a potential and novel way of impact of TNF- $\alpha$ on breast cancer aetiology and may provide a new understanding in the link between obesity and increased risk of breast cancer development.

\section{Acknowledgements}

M.W. was supported by R\&D Initiative, Robert Gordon University; Breast Cancer Campaign supported part of the study.

\section{References}

1. Calle EE, Rodriguez C, Walker-Thurmond $\mathrm{K}$ and Thun MJ: Overweight, obesity, and mortality from cancer in a prospectively studied cohort of U.S. adults. N Engl J Med 348: 1625-1638, 2003. 
2. Lahmann PH, Hoffmann K, Allen N, van Gils $\mathrm{CH}$, Khaw KT, Tehard B, Berrino F, Tjonneland A, Bigaard J, Olsen A, Overvad K, Clavel-Chapelon F, Nagel G, Boeing H, Trichopoulos D, Economou G, Bellos G, Palli D, Tumino R, Panico S, Sacerdote C, Krogh V, Peeters PH, Bueno-deMesquita HB, Lund E, Ardanaz E, Amiano P, Pera G, Quiros JR, Martinez C, Tormo MJ, Wirfalt E, Berglund G, Hallmans G, Key TJ, Reeves G, Bingham S, Norat T, Biessy C, Kaaks R and Riboli E: Body size and breast cancer risk: findings from the European prospective investigation into cancer and nutrition (EPIC). Int J Cancer 111: 762-771, 2004

3. Abrahamson PE, Gammon MD, Lund MJ, Flagg EW, Porter PL, Stevens J, Swanson CA, Brinton LA, Eley JW and Coates RJ: General and abdominal obesity and survival among young women with breast cancer. Cancer Epidemiol Biomarkers Prev 15: 1871-1877, 2006.

4. Fain JN, Madan AK, Hiler ML, Cheema P and Bahouth SW: Comparison of the release of adipokines by adipose tissue, adipose tissue matrix, and adipocytes from visceral and subcutaneous abdominal adipose tissues of obese humans. Endocrinology 145: 2273-2282, 2004.

5. Trayhurn P and Wood IS: Adipokines: inflammation and the pleiotropic role of white adipose tissue. Br J Nutr 92: 347-355, 2004.

6. Samaras K, Botelho NK, Chisholm DJ and Lord RV: Subcutaneous and visceral adipose tissue gene expression of serum adipokines that predict type 2 diabetes. Obesity (Silver Spring) 18: 884-889, 2010.

7. Considine RV, Sinha MK, Heiman ML, Kriauciunas A, Stephens TW, Nyce MR, Ohannesian JP, Marco CC, McKee LJ, Bauer TL and Caro JF: Serum immunoreactive-leptin concentrations in normal-weight and obese humans. N Engl J Med 334: 292-295, 1996.

8. Park HS, Park JY and Yu R: Relationship of obesity and visceral adiposity with serum concentrations of CRP, TNF-alpha and IL-6. Diabetes Res Clin Pract 69: 29-35, 2005.

9. Olszanecka-Glinianowicz M, Zahorska-Markiewicz B, Janowska J and Zurakowski A: Serum concentrations of nitric oxide, tumor necrosis factor (TNF)-alpha and TNF soluble receptors in women with overweight and obesity. Metabolism 53: 1268-1273, 2004.

10. Black RA, Rauch CT, Kozlosky CJ, Peschon JJ, Slack JL, Wolfson MF, Castner BJ, Stocking KL, Reddy P, Srinivasan S, Nelson N, Boiani N, Schooley KA, Gerhart M, Davis R, Fitzner JN, Johnson RS, Paxton RJ, March CJ and Cerretti DP: A metalloproteinase disintegrin that releases tumour-necrosis factor-alpha from cells. Nature 385: 729-733, 1997.

11. Carswell EA, Old LJ, Kassel RL, Green S, Fiore N and Williamson B: An endotoxin-induced serum factor that causes necrosis of tumors. Proc Natl Acad Sci USA 72: 3666-3670, 1975.

12. Krajewska M, Krajewski S, Zapata JM, Van Arsdale T, Gascoyne RD, Berern K, McFadden D, Shabaik A, Hugh J, Reynolds A, Clevenger CV and Reed JC: TRAF-4 expression in epithelial progenitor cells: analysis in normal adult, fetal, and tumor tissues. Am J Pathol 152: 1549-1561, 1998.

13. Rivas MA, Carnevale RP, Proietti CJ, Rosemblit C, Beguelin W, Salatino M, Charreau EH, Frahm I, Sapia S, Brouckaert P, Elizalde PV and Schillaci R: TNF alpha acting on TNFR1 promotes breast cancer growth via p42/P44 MAPK, JNK, akt and NF-kappa B-dependent pathways. Exp Cell Res 314: 509-529, 2008.

14. Pusztai L, Lewis CE and McGee JO: Growth arrest of the breast cancer cell line, T47D, by TNF alpha; cell cycle specificity and signal transduction. Br J Cancer 67: 290-296, 1993.

15. Lee SH and Nam HS: TNF alpha-induced down-regulation of estrogen receptor alpha in MCF-7 breast cancer cells. Mol Cells 26: 285-290, 2008.

16. Bogin L, Papa MZ, Polak-Charcon S and Degani H: TNFinduced modulations of phospholipid metabolism in human breast cancer cells. Biochim Biophys Acta 1392: 217-232, 1998.

17. Burow ME, Weldon CB, Tang Y, Navar GL, Krajewski S, Reed JC, Hammond TG, Clejan S and Beckman BS: Differences in susceptibility to tumor necrosis factor alpha-induced apoptosis among MCF-7 breast cancer cell variants. Cancer Res 58: 4940-4946, 1998.
18. Hollestelle A, Elstrodt F, Nagel JH, Kallemeijn WW and Schutte M: Phosphatidylinositol-3-OH kinase or RAS pathway mutations in human breast cancer cell lines. Mol Cancer Res 5: 195-201, 2007

19. Lorincz AM and Sukumar S: Molecular links between obesity and breast cancer. Endocr Relat Cancer 13: 279-292, 2006.

20. Housa D, Housova J, Vernerova Z and Haluzik M: Adipocytokines and cancer. Physiol Res 55: 233-244, 2006.

21. Hou WK, Xu YX, Yu T, Zhang L, Zhang WW, Fu CL, Sun Y, $\mathrm{Wu} \mathrm{Q}$ and Chen L: Adipocytokines and breast cancer risk. Chin Med J (Engl) 120: 1592-1596, 2007.

22. Nkhata KJ, Ray A, Schuster TF, Grossmann ME and Cleary MP: Effects of adiponectin and leptin co-treatment on human breast cancer cell growth. Oncol Rep 21: 1611-1619, 2009.

23. Frankenberry KA, Skinner H, Somasundar P, McFadden DW and Vona-Davis LC: Leptin receptor expression and cell signaling in breast cancer. Int J Oncol 28: 985-993, 2006.

24. Garofalo C and Surmacz E: Leptin and cancer. J Cell Physiol 207: 12-22, 2006.

25. Dieudonne MN, Machinal-Quelin F, Serazin-Leroy V, Leneveu MC, Pecquery R and Giudicelli Y: Leptin mediates a proliferative response in human MCF7 breast cancer cells. Biochem Biophys Res Commun 293: 622-628, 2002.

26. O'brien SN, Welter BH and Price TM: Presence of leptin in breast cell lines and breast tumors. Biochem Biophys Res Commun 259: 695-698, 1999.

27. Dos Santos E, Benaitreau D, Dieudonne MN, Leneveu MC, Serazin V, Giudicelli Y and Pecquery R: Adiponectin mediates an antiproliferative response in human MDA-MB 231 breast cancer cells. Oncol Rep 20: 971-977, 2008.

28. Korner A, Pazaitou-Panayiotou K, Kelesidis T, Kelesidis I, Williams CJ, Kaprara A, Bullen J, Neuwirth A, Tseleni S, Mitsiades N, Kiess W and Mantzoros CS: Total and highmolecular-weight adiponectin in breast cancer: in vitro and in vivo studies. J Clin Endocrinol Metab 92: 1041-1048, 2007.

29. Dieudonne MN, Bussiere M, Dos Santos E, Leneveu MC, Giudicelli $Y$ and Pecquery R: Adiponectin mediates antiproliferative and apoptotic responses in human MCF7 breast cancer cells. Biochem Biophys Res Commun 345: 271-279, 2006.

30. Mueller H, Flury N, Liu R, Scheidegger S and Eppenberger U: Tumour necrosis factor and interferon are selectively cytostatic in vitro for hormone-dependent and hormone-independent human breast cancer cells. Eur J Cancer 32A: 2312-2318, 1996.

31. Rivas MA, Tkach M, Beguelin W, Proietti CJ, Rosemblit C, Charreau EH, Elizalde PV and Schillaci R: Transactivation of ErbB-2 induced by tumor necrosis factor alpha promotes NF-kappaB activation and breast cancer cell proliferation. Breast Cancer Res Treat 122: 111-124, 2010.

32. Kurebayashi J: Biological and clinical significance of HER2 overexpression in breast cancer. Breast Cancer 8: 45-51, 2001.

33. Ip MM, Shoemaker SF and Darcy KM: Regulation of rat mammary epithelial cell proliferation and differentiation by tumor necrosis factor-alpha. Endocrinology 130: 2833-2844, 1992.

34. Varela LM, Stangle-Castor NC, Shoemaker SF, Shea-Eaton WK and Ip MM: TNFalpha induces NFkappaB/p50 in association with the growth and morphogenesis of normal and transformed rat mammary epithelial cells. J Cell Physiol 188: 120-131, 2001.

35. Scheid MP and Woodgett JR: Phosphatidylinositol 3' kinase signaling in mammary tumorigenesis. J Mammary Gland Biol Neoplasia 6: 83-99, 2001.

36. Reddy KB, Nabha SM and Atanaskova N: Role of MAP kinase in tumor progression and invasion. Cancer Metastasis Rev 22: 395-403, 2003.

37. McCubrey JA, Steelman LS, Chappell WH, Abrams SL, Wong EW, Chang F, Lehmann B, Terrian DM, Milella M, Tafuri A, Stivala F, Libra M, Basecke J, Evangelisti C, Martelli AM and Franklin R: Roles of the Raf/MEK/ERK pathway in cell growth, malignant transformation and drug resistance. Biochim Biophys Acta 1773: 1263-1284, 2007.

38. Kim S, Choi JH, Kim JB, Nam SJ, Yang JH, Kim JH and Lee JE: Berberine suppresses TNF-alpha-induced MMP-9 and cell invasion through inhibition of AP-1 activity in MDAMB-231 human breast cancer cells. Molecules 13: 2975-2985, 2008. 